\title{
Karakterisasi Buah Mangga Berdasarkan Nilai Dielektrik Menggunakan Teknik Double-Ring Resonator
}

\author{
Mango Fruit Characterization Based on Dielectric Value \\ UsingDouble-Ring Resonator Technique \\ Suthami Ariessaputra ${ }^{1}$, Cahyo Mustiko Okta Muvianto ${ }^{1 *}$, Kurniawan Yuniarto ${ }^{2}$, Sudi M. Al \\ Sasongko ${ }^{1}$, dan Syafaruddin $\mathrm{Ch}^{1}$ \\ ${ }^{1}$ Jurusan Teknik Elektro, Fakultas Teknik, Universitas Mataram \\ ${ }^{2}$ Program Studi Teknik Pertanian, Fakultas Teknologi Pangan \& Agroindustri, Universitas Mataram \\ *corresponding author, email: cahyo.muvianto@unram.ac.id
}

Manuscript received: 02-01-2020. Accepted: 29-05-2020

\begin{abstract}
ABSTRAK
Mangga merupakan salah satu produk pertanian di Provinsi Nusa Tenggara Barat. Kualitas dari buah mangga pascapanen juga perlu diketahui agar mutu yang dihasilkan tetap terjaga. Mutu buah di daerah tropis dapat ditinjau dari laju respirasi, kekencangannya, Susut bobot, Total Padatan Terlarut (TPT), Perubahan Warna dan kadar asam. Selain itu kualitas buah mangga pasca panen juga dapat dideteksi menggunakan sensor yang memancarkan gelombang mikro dengan nilai tertentu. Teknik ini bersifat non-destruktif sehingga tidak merusak objek yang digunakan. Gelombang mikro di pancarkan melalui sensor jenis double-ring resonator. Vector Network Analyzer (VNA) digunakan sebagai alat bantu untuk menghasilkan nilai skatering $S_{11}$ dan $S_{21}$, nilai skatering selanjutnya diolah menjadi nilai dielektrik. Pengujian dilakukan pada buah mangga jenis gedong gincu yang terbagi dalam 4 kategori yaitu buah mangga matang di pohon, matang sekali, mengkal dan mentah. Sensor double ring resonator dapat mendeteksi dan membedakan tingkat kematangan buah mangga berdasarkan nilai $\mathrm{S}_{21}$ pada rentang frekuensi $0,39-0,49 \mathrm{GHz}$. Pada rentang frekuensi tersebut, nilai gain rata-rata buah mangga yang matang dipohon $-21,4 \mathrm{~dB}$, buah mangga matang sekali $-22,8 \mathrm{~dB}$, mangga mengkal $-25,4 \mathrm{~dB}$ dan mangga mentah $-33,4 \mathrm{~dB}$. Sedangkan karakterisasi buah mangga menggunakan nilai impedansi dapat dilihat pada rentang frekuensi $0,41-0,47 \mathrm{GHz}$. Nilai impedansi rata-rata buah mangga yang matang di pohon sebesar 0,073, mangga matang sekali 0,067, mangga mengkal 0,057 dan mangga mentah 0,032.
\end{abstract}

Kata kunci: manga; non-destruktif; double-ring resonator; gelombang mikro; dielektrik

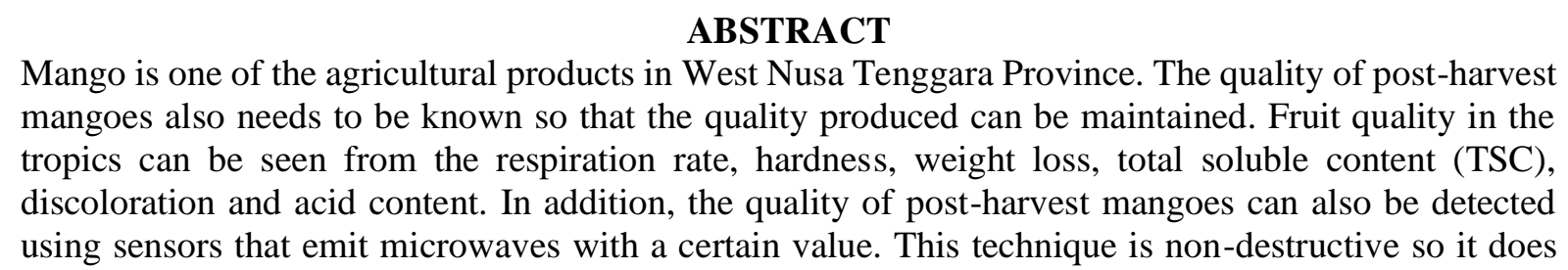


not damage the object used. Double-ring resonators are used as sensors to detect the characteristics of mangoes. Vector Network Analyzer (VNA) is used as a tool to produce S11 and S21 skatering values, then the skatering values are processed into dielectric values. The test was carried out on the type of Gincong Gincu Mango which was divided into 4 categories, namely ripe mango on the tree, very ripe, thick and raw. Double ring resonator sensor can detect and distinguish the maturity level of mangoes based on the value of $S_{21}$ in the frequency range of 0.39 to $0.49 \mathrm{GHz}$. In that frequency range, the average gain value of ripe on tree is $-21.4 \mathrm{~dB}$, over ripe is $-22.8 \mathrm{~dB}$, early ripe is $-25.4 \mathrm{~dB}$ and unrip mango is $-33.4 \mathrm{~dB}$. While the characterization of mangoes using impedance values can be seen in the frequency range of $0.41-0.47 \mathrm{GHz}$. The average impedance value of ripe on tree is about 0.073 , over ripe is about 0.067 , early ripe is about 0.057 and unripe mangos is about 0.032 .

Keyword: mango; non-destructive; double-ring resonator; microwave; dielectric

\section{PENDAHULUAN}

Indonesia termasuk negara tropis yang terletak di garis katulistiwa sehingga memiliki keragaman dan kekayaan hayati diantaranya adalah buah buahan. Konsumsi buah - buahan segar cenderung mengalami peningkatan, hal ini disebabkan karena kebutuhan dan kesadaran masyarakat dunia akan khasiatnya termasuk juga Indonesia. Indonesia diharapkan mampu memberikan peran lebih banyak dalam memenuhi kebutuhan buah dalam negeri dan juga dapat berperan lebih besar untuk mengekspor buah segar yang berkualitas ke negara-negara besar, seperti Inggris, Singapura dan Malaysia. Ekspor buah tersebut antara lain buah mangga, nanas, jambu biji, pepaya, dan pisang (Oktavianto et al., 2015).

Provinsi Nusa Tenggara Barat merupakan salah satu penghasil buah mangga. Produksi buah mangga di Pronvinsi NTB pada tahun 2017 mencapai 165.000 ton dari sekitar 1.000.000 pohon mangga yang ada. Hampir seluruh kabupaten/kota se-NTB setiap tahunnya mampu menghasilkan buah mangga, namun pusat produksinya berada di daerah Sumbawa yang dapat memproduksi sekitar 44.000 ton mangga dan Lombok Tengah dengan produksi mencapai sekitar 36.000 ton. Sementara itu wilayah Mataram dan Sumbawa Barat merupakan wilayah yang paling sedikit menghasilkan buah mangga, tepatnya 811 ton untuk Kota Mataram sedangkan 1.988 ton untuk Kabupaten Sumbawa Barat (Kemendag, 2017).

Kualitas buah mangga yang di panen dapat ditinjau dari beberapa karakteristik seperti: ukuran buahnya, tulang daunnya (Riska et al., 2015) kadar keasaman, level kemanisan, kekencangannya dan corak warna pada kulitnya ( Dimas dan Sutojo, 2015). Ada dua teknik yang biasanya digunakan untuk menilai kualitas buah. Teknik pertama yaitu dengan memperoleh sifat karakteristik fisikokimia seperti gradasi warna dan $\mathrm{pH}$. Teknik ini memberikan informasi yang akurat tentang kandungan yang terdapat dalam buah, tetapi membutuhkan waktu yang relatif lama karena objek yang di uji harus dilebur agar menjadi lebih cair. Oleh karena itu diperlukan beberapa kegiatan tambahan seperti mengupas, mengiris, memeras, melubangi, menghaluskan bentuk atau membuat jus buah sehingga di peroleh sampel cairan. Akibatnya terdapat sisa-sisa bahan dari proses tersebut yang tidak terpakai.

Metode yang kedua adalah teknik non-destruktif yaitu teknik ini mengukur objek tanpa merusak objek yang diuji dengan waktu yang relatif cepat. Teknik pengukuran seperti dapat dilakukan dengan memancarkan gelombang elektromagnetik menggunakan antena yang di fungsikan sebagai sebuah sensor. Teknik ini menghasilkan nilai dielektrik yang selanjutnya dapat digunakan untuk mengetahui karakteritik buah mangga tersebut (Monai et al, 2004). 
Mangga dan beberapa buah yang lainnya serta sayuran juga telah diukur nilai dielektriknya menggunakan beberapa jenis sensor yang berbeda (Reyes et al., 2017).

Pengukuran dielektrik buah mangga memanfaatkan gelombang mikro juga sudah dilakukan menggunakan model open-ended coaxial probe. Namun objek buah mangga harus dilubangi terlebih dahulu, sehingga sensor bisa masuk kedalam daging buah untuk dapat mengukur nilai dielektriknya (Harshitha et al., 2017). Biji beras juga dapat diukur kualitasnya menggunakan teknik gelombang mikro yang menggunakan model sensor mikrostrip wide-ring dan mikrostrip coupled-line. Teknik ini menghasilkan error sebesar 9,7\% (You et al, 2013). Pengukuran nilai dielektrik dan konduktivitas berupa cairan madu (Syafrin et al., 2018) dan cairan darah pada manusia juga sudah dilakukan menggunakan sensor microstrip split-ring (Zhang et al., 2018).

Berdasarkan hal tersebut tersebut, maka penulis akan mengukur karakteristik buah mangga berdasarkan nilai dielektrik menggunakan teknik double-Ring Resonator dengan memanfaatkan gelombang mikro yang bekerja pada frekuensi $100 \mathrm{MHz}-3 \mathrm{GHz}$. Kelebihan teknik ini adalah bersifat non destructive, artinya tidak perlu merusak dan menghancurkan objek buah mangga yang akan diuji. Selain itu tidak diperlukan matching dari sampel yang digunakan serta mudah dalam menyiapkan bahan ujinya, setelah alat ukur dikalibrasi, selanjutnya nilai dielektrik dari sampel dalam jumlah besar dapat diukur secara langsung dengan cepat, dan pengukuran dapat dilakukan pada suhu ruangan. Buah mangga yang digunakan sebagai bahan uji adalah buah mangga jenis gedong gincu yang memiliki beberapa tingkat kematangan. Selanjutnya nilai dielektrik digunakan untuk melihat karakteristik buah mangga tersebut.

\section{BAHAN DAN METODE}

Pada penilitian ini terdiri dari beberapa tahap yaitu: survey buah mangga, perancangan dan pembuatan sensor, pengukuran nilai dielektrik menggunakan sensor dan mengukur tingkat kemanisan menggunakan metode total padatan terlarut. Sampel buah mangga yang digunakan memiliki tingkat kematangan yang berbeda. Buah mangga terlebih dahulu diukur nilai dielektriknya, setelah itu pada sampel mangga yang sama dan hari yang sama dilakukan pengukuran kadar gula. Selanjutnya kedua hasil pengukuran dari metode yang berbeda tersebut dibandingkan untuk mencari korelasinya.

\section{Bahan Penelitian}

Bahan yang digunakan adalah buah mangga gedong gincu yang dipanen di Pulau Lombok Provinsi Nusa tenggara Barat. Buah tersebut terbagi menjadi empat kategori yaitu : buah mangga matang di pohon, matang sekali, mengkal dan mentah. Pada setiap kategori disiapkan masing-masing empat buah mangga. Sedangkan bahan pembuatan sensor menggunakan PCB double layer dan konektor sma.

Buah mangga terlebih dahulu diukur nilai dielektriknya, setelah itu pada sampel mangga yang sama dan hari yang sama dilakukan pengukuran kadar gula menggunakan metode total padatan terlarut. 


\section{Desain Split-Ring Resonator}

Perancangan sensor terdiri dari perhitungan matematis, simulasi dan realisasi sensor. Perhitungan matematis dilakukan untuk mengetahui dimensi sensor yang dibuat dengan model Double-Ring Resonator. Selanjutnya dilakukan simulasi untuk mengetahui nilai-nilai parameter dari sensor tersebut. Setelah nilai-nilai parameter sesuai dengan rancangan, selanjutnya masuk pada tahap pembuatan sensor menggunakan $\mathrm{PCB}$ double layer.

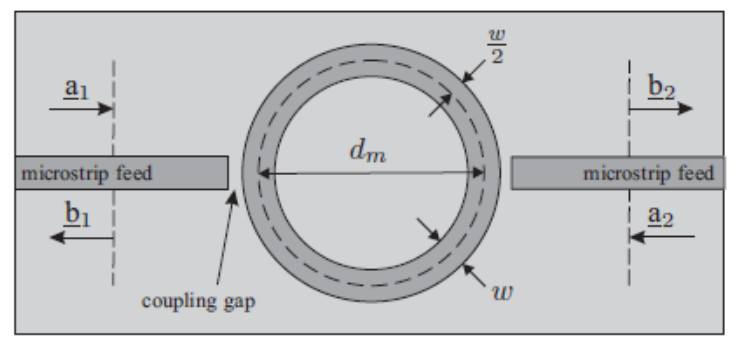

Gambar 1. Sekmatik rangkaian ring resonator

Resonator cincin mikrostrip sering digunakan untuk menentukan karakteristik substrat gelombang mikro, khususnya konstanta dielektrik dan loss tangen. Frekuensi resonansi cincin dapat dihitung dari persamaan.

$$
n \cdot \lambda_{\text {res, } n}=\pi \cdot d_{m}
$$

dimana $\mathrm{n}$ adalah bilangan harmonik, $\lambda_{\text {res, } \mathrm{n}}$ adalah panjang gelombang resonansi, $\pi$ adalah angka $\mathrm{Pi}$, dan $\mathrm{dm}$ adalah diameter rata-rata cincin.

\section{Rangkaian Ekuivalen}

Rangkaian ekuivalen elemen yang disatukan dari DSRR diilustrasikan pada Gambar 2. Cincin-split tunggal ekivalen sebagai resonator LC seri karena memiliki induktansi (L) dari cincin dan kapasitansi (C) dari celah. Hal ini ditunjukkan pada Gambar 2.a, yang menunjukkan puncak tunggal dalam karakteristik transmisi. Ketika dua cincin ditempatkan secara paralel, kita harus memperhitungkan induktansi timbal balik $(\mathrm{M})$ dan kapasitif kopling $\left(\mathrm{C}_{\mathrm{p}}\right)$ di antara mereka, seperti yang ditunjukkan pada Gambar 2.b.

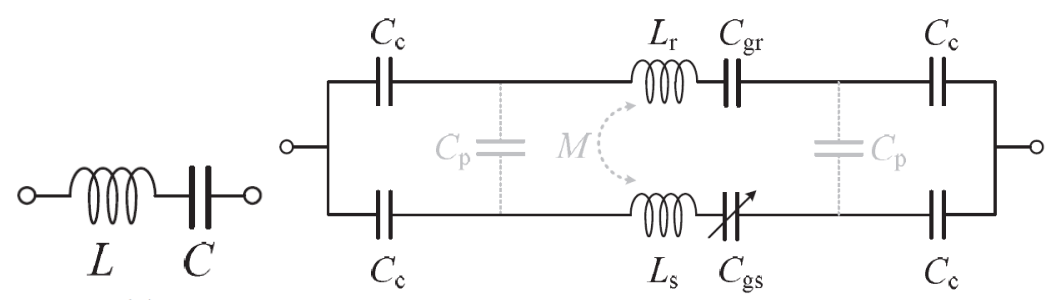

(a)

(b)

Gambar 2.a resonator seri LC, 2.b Rangkaian ekuivalen double ring resonator.

Kapasitor $\mathrm{C}_{\mathrm{c}}$ mewakili kopling input / output untuk setiap cincin, yang harus identik untuk operasi input / ouput seimbang dan faktor kualitas tinggi. $\mathrm{L}_{\mathrm{r}}$ dan $\mathrm{C}_{\mathrm{gr}}$ masing-masing adalah induktansi setara dan kapasitansi celah dari cincin referensi, sedangkan $L_{s}$ dan $C_{g}$ adalah kapasitansi induktansi dan celah yang setara dari cincin. 


\section{Dimensi Sensor}

Gambar 3 menunjukkan gambar dari dimensi sensor berdasarkan pada sepasang SplitRing Resonator dengan frekuensi yang sedikit berbeda, yang kita sebut Double Split-Ring Resonator (DSRR). Sensor dibuat dari bahan PCB double layer dengan ukuran lingkaran dalam rb sebesar $2 \mathrm{~mm}$ yang memiliki frekuensi resonansi sekitar 1,2 GHz. Frekuensi resonansi dapat diubah dengan mengubah diameter cincin.

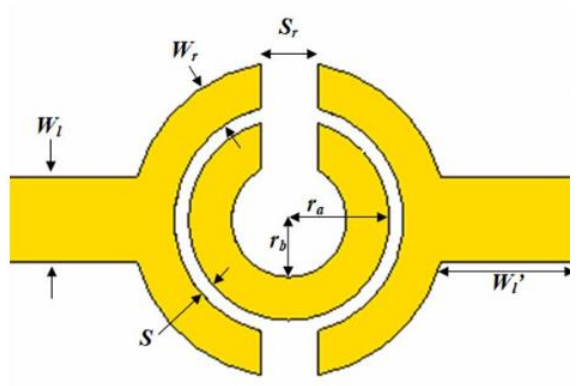

Gambar 3. Dimensi sensor

Keterangan :

- $\quad L \quad$ : Lebar Substrat $(18 \mathrm{~mm})$

- $W_{l} \quad$ : Lebar pencatu $(3 \mathrm{~mm})$

- $\quad W_{l}$ ' : Panjang pencatu $(5 \mathrm{~mm})$

- $S \quad$ : Jarak ring pertama dengan ring kedua/gap $(0.5 \mathrm{~mm})$

- $S_{r} \quad$ : Jarak perpotongan pada ring $(3 \mathrm{~mm})$

- $\quad W_{r} \quad$ : Lebar Ring $(3 \mathrm{~mm})$

- $\quad R_{a} \quad$ : Jari - jari luar $(3.5 \mathrm{~mm})$

- $\quad R_{b} \quad$ : Jari - jari dalam $(2 \mathrm{~mm})$

\section{Skema Pengukuran}

Pada gambar 4 merupakan Instrumen pengukuran yang digunakan untuk menentukan nilai dielektrik buah mangga menggunakan teknik Split-Ring Resonator, dan Vector Network Analyzer (VNA) pada frekuensi gelombang mikro. Pengambilan data dilakukan dengan mendekatkan dan menyentuhkan double-ring resonator ke objek mangga.

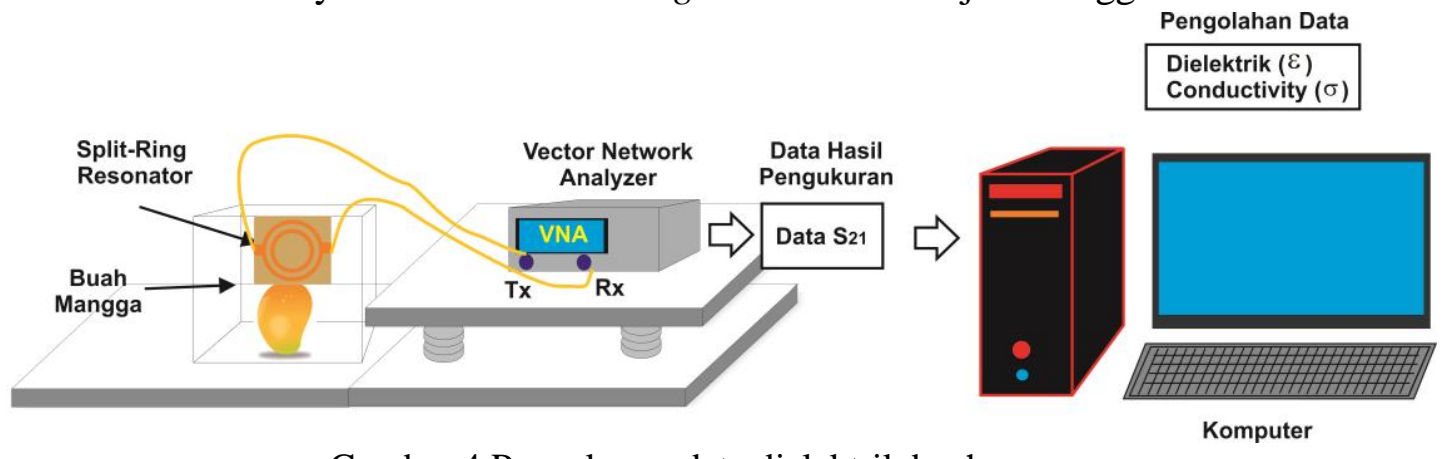

Gambar 4.Pengukuran data dielektrik buah mangga

Sensor dari Double-Ring Resonator selanjutnya dihubungkan dengan Vector Network Analyzer (VNA). VNA dapat mengukur karakteristik buah mangga sesuai dengan frekuensi $100 \mathrm{MHz}$ sampai $3 \mathrm{GHz}$ (lebar pita $2900 \mathrm{MHz}$ ). Data yang dihasilkan VNA berupa nilai $\mathrm{S}_{21}$ yang selanjutnya diolah menjadi nilai dielektrik. 
Nilai dielektrik yang diperoleh dari sampel mangga yang diukur merupakan mangga matang dengan beberapa kondisi, yaitu mangga mentah, mengkal, matang di pohon dan matang sekali. Berdasarkan kondisi tersebut akan diperoleh data ukur yang relatif banyak. Selanjutnya data tersebut akan diolah dan dianalisa karakteristik masing-masing menggunakan software. Pengukuran buah mangga gedung gincu dapat dilihat pada gambar 5. Tampak pada gambar bahwa sensor ditempelkan pada permukaan buah mangga. Setelah dilakukan pengukuran dapat diperoleh nilai $S_{21}$ dan impedansi.

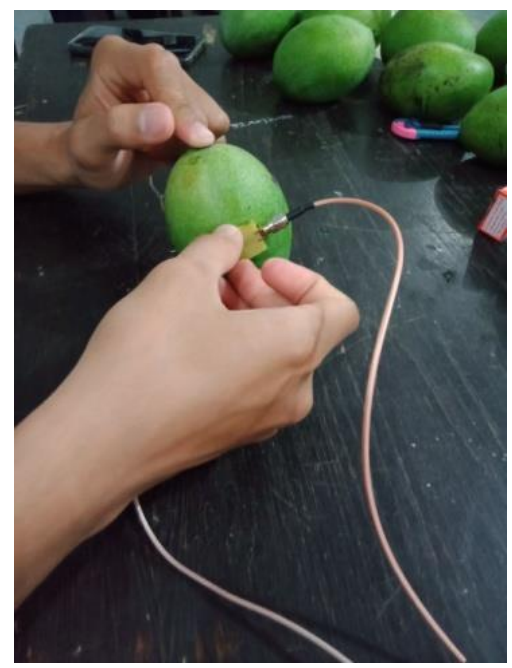

Gambar 5. Pengukuran Dielektrik Buah Mangga

\section{Pengujian Total Padatan Terlarut}

Pengujian nilai total padatan terlarut dilakukan menggunakan alat ukur handrefractometer. Alat ukur refraktometer terlebih dahulu dibersihkan dengan aquades dan dibersihkan menggunakan kain yang memiliki tekstur lembut. Selanjutnya sampel buah yang telah encer diteteskan ke atas permukaan prisma refraktometer dan diukur nilai derajat Brixnya (Wahyudi dan Dewi, 2017). Pengujian nilai total padatan terlarut untuk kadar gula buah mangga dapat dilihat pada gambar 6 .

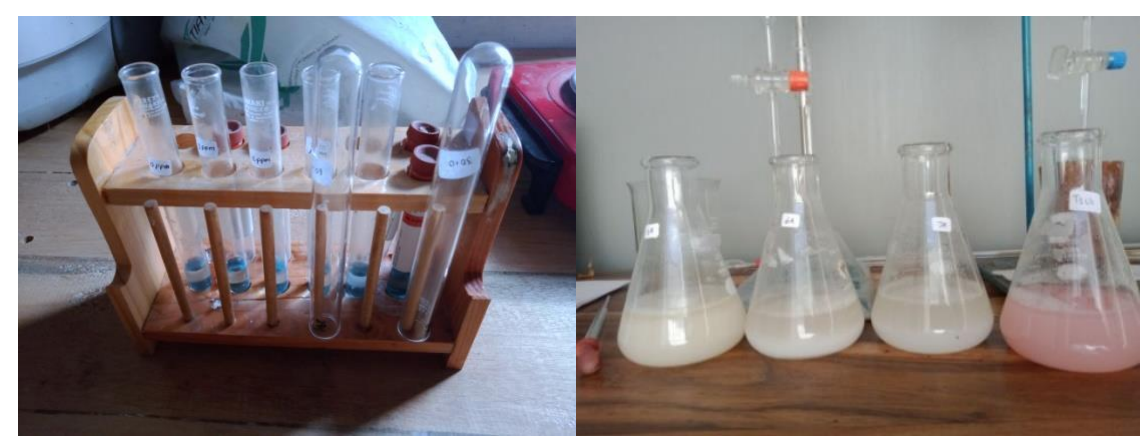

Gambar 6. Buah mangga yang sudah dicairkan. 


\section{HASIL DAN PEMBAHASAN}

Hasil pengujian yang dilakukan terdiri dari hasil pengujian sensor double ring resonator dan pengukuran kadar gula.

\section{Hasil Sensor Double Ring}

Sensor double ring resonator terbuat dari bahan PCB. Hasil sensor yang telah dibuat dapat dilihat pada gambar 7. Tampak pada gambar bahwa sensor memiliki dua port yang terdiri dari satu port input (Tx) dan satu port output $(\mathrm{Rx})$.

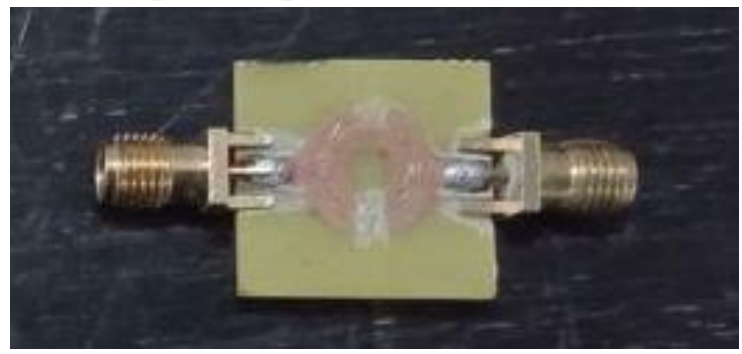

Gambar 7. Sensor double ring

\section{Hasil Pengukuran Nilai Dielektrik}

Pengukuran nilai dielektrik buah mangga gedong gincu terdiri dari pengukuran nilai $\mathrm{S}_{21}$ dan nilai impedansi. Hasil pengukuran ini digunakan untuk melihat karakteristik masingmasing buah mangga tersebut.

\section{Hasil Pengukuran Nilai $S_{21}$}

Nilai $S_{21}$ yang diperoleh dtampilkan pada grafik. Gambar 8 menunjukkan nilai dari $S_{21}$ untuk 4 kategori buah mangga yang berbeda-beda. Nilai $S_{21}$ untuk masing-masing kategori juga mengalami nilai yang fluktuatif. Nilai $S_{21}$ berkisar antara $-13 \mathrm{~dB}$ sampai dengan $-48 \mathrm{~dB}$. Nilai yang dihasilkan fluktuatif pada rentang frekuensi $0-3 \mathrm{GHz}$. Pada frekuensi 1,2 GHz nilai $\mathrm{S}_{21}$ tertinggi dimiliki oleh mangga matang sekali sebesar -23, sedangkan nilai terendah dimiliki oleh mangga mentah sebesar -33 .

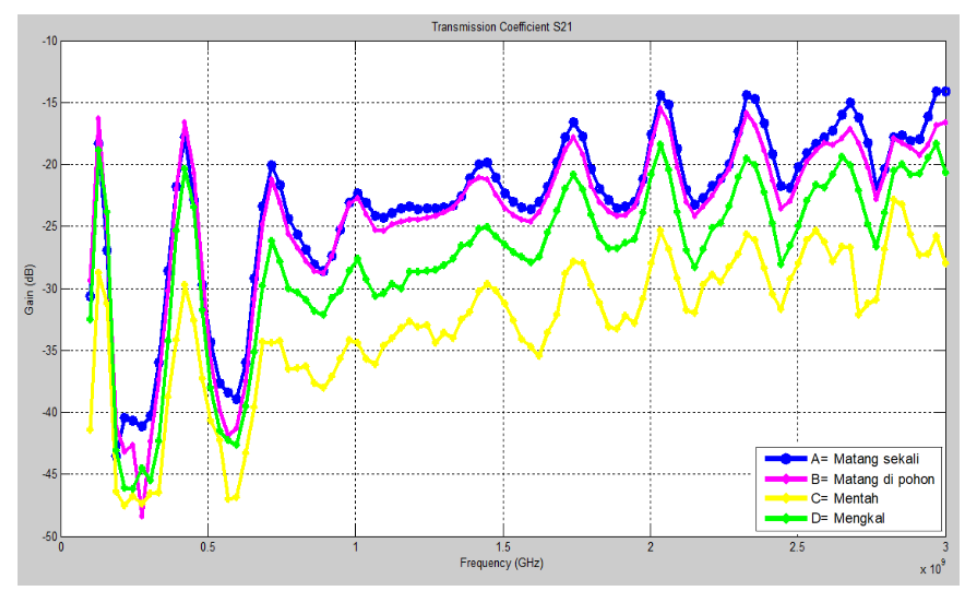

Gambar 8. Nilai $\mathrm{S}_{21}$ pada frekuensi 0-3 GHz 


\section{Hasil Pengukuran Impedansi}

Hasil pengukuran nilai impedansi $S_{21}$ terdiri dari nilai real dan imajiner seperti terlihat pada gambar 9. Nilai imepedansi $S_{21}$ yang diperoleh berkisar antara 0 sampai 7 dari keempat jenis kategori tersebut. Pada frekuensi kerjanya di $1,2 \mathrm{GHz}$ Nilai impedansi terendah yaitu 0,15 pada sampel buah matang di pohon dan matang sekali, sedangkan impedansi tertinggi terdapat pada buah mangga mentah sebesar 0,85 .

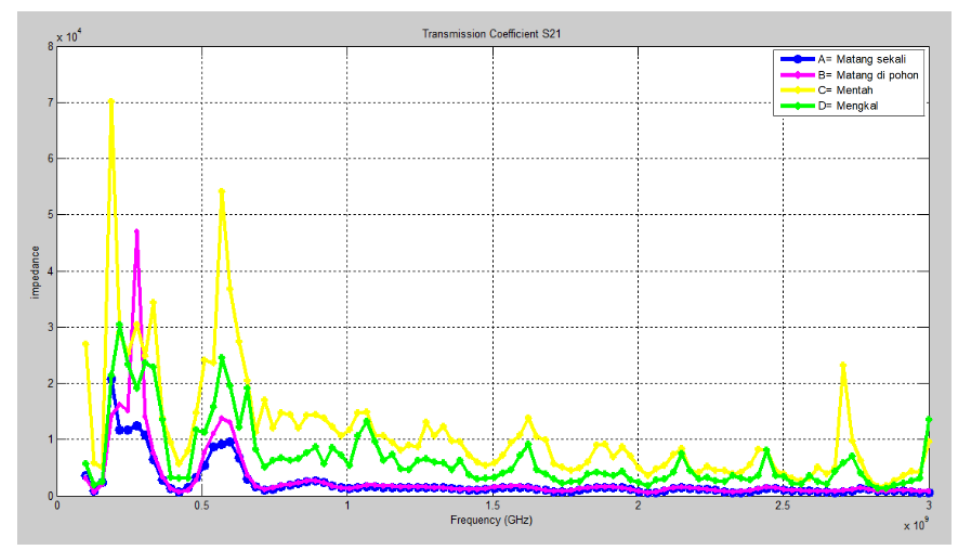

Gambar 9. Nilai Impedansi $S_{21}$ pada frekuensi 0-3 GHz

Nilai imepedansi $S_{21}$ yang diperoleh berkisar antara 0 sampai 7. Sedangkan nilai imepedansi imajiner $S_{21}$ yang diperoleh berkisar antara 0,17 sampai -0,12 seperti terlihat pada gambar 10 .

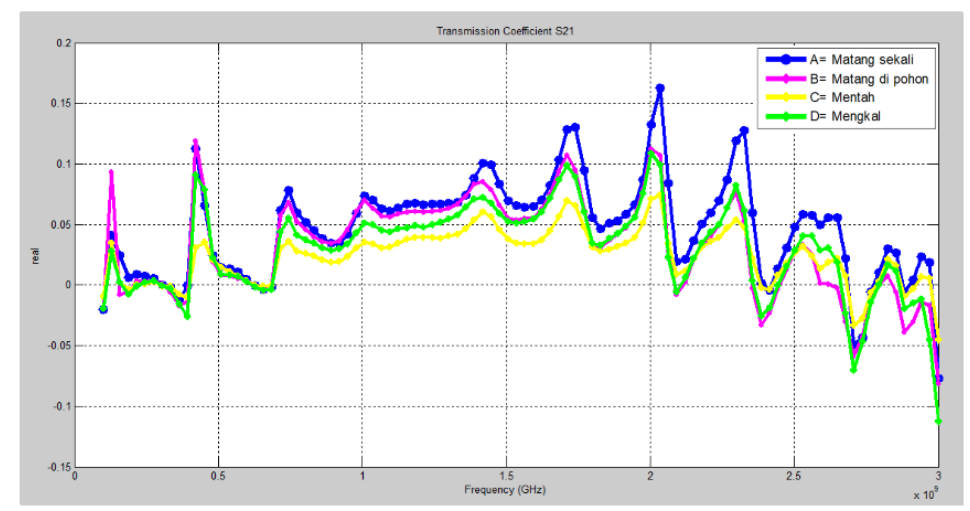

Gambar 10. Nilai Impedansi real $S_{21}$ pada frekuensi 0-3 GHz

\section{Hasil Pengukuran kadar gula}

Hasil pengukuran kadar gula yang diperoleh dari pengujian total padatan terlarut dapat dilihat pada tabel 1. Nilai kadar gula dinyatakan dalam derajat BRIX ( ${ }^{\circ}$ BRIX). Selanjutnya data hasil pengukuran pada tabel 1 dibuat kedalam bentuk grafik seperti terlihat pada gambar 11. Nilai rata-rata kadar kemanisan (kadar gula) tertinggi terdapat pada buah mangga matang di pohon sebesar 21,18 derajat BRIX, sedangkan terendah pada mangga mentah sebesar 8,93 derajat BRIX. 
Tabel 1. Kadar Gula dalam buah mangga

\begin{tabular}{|c|c|c|c|c|}
\hline Kategori Buah & mangga & ${ }^{\circ}$ Brix & Rata-rata & Standar Deviasi \\
\hline \multirow{4}{*}{ Sangat Matang } & A1.1 & 20.25 & \multirow{4}{*}{20.53} & \multirow{4}{*}{0.6} \\
\hline & A1.2 & 19.85 & & \\
\hline & A2.1 & 21.2 & & \\
\hline & A2.2 & 20.8 & & \\
\hline \multirow{4}{*}{ Matang di Pohon } & B1.1 & 19.3 & \multirow{4}{*}{21.18} & \multirow{4}{*}{1.82} \\
\hline & B2.2 & 23.65 & & \\
\hline & B3.1 & 22.2 & & \\
\hline & B3.2 & 22.1 & & \\
\hline \multirow{4}{*}{ Mentah } & C2.1 & 10.2 & \multirow{4}{*}{8.93} & \multirow{4}{*}{1.15} \\
\hline & $\mathrm{C} 2.2$ & 9.55 & & \\
\hline & C3.1 & 7.7 & & \\
\hline & C3.2 & 8.25 & & \\
\hline \multirow{4}{*}{ Mengkal } & D1.1 & 14.75 & \multirow{4}{*}{14.76} & \multirow{4}{*}{0.98} \\
\hline & D1.2 & 14.1 & & \\
\hline & D3.1 & 14.05 & & \\
\hline & D3.2 & 16.15 & & \\
\hline
\end{tabular}

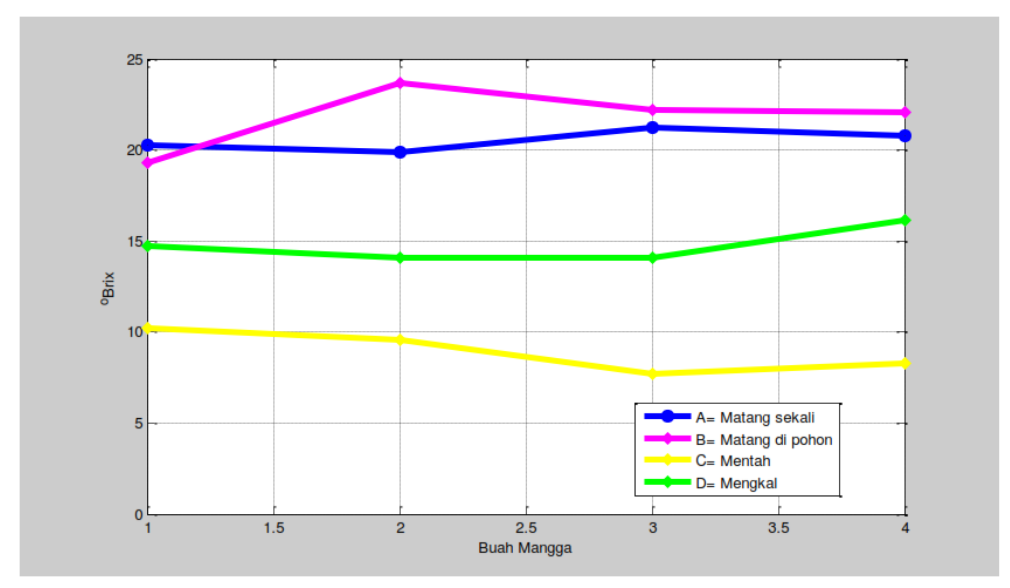

Gambar 11. Nilai Kadar Gula

\section{Hubungan Nilai Gain $S_{21}$ dengan Kadar Gula}

Tren hubungan antara nilai dielektrik dengan kadar kemanisan dapat dilihat dengan membandingkan nilai gain $S_{21}$ dengan nilai kadar gulanya. Pada perbandingan gambar 11 dengan 12, menunjukkan kecenderungan perbandingan linier antara nilai $S_{21}$ dengan nilai kadar gulanya yaitu pada rentang frekuensi 0,39 sampai $0,49 \mathrm{GHz}$. Pada rentang frekuensi tersebut buah mangga yang matang dipohon memiliki nilai gain rata-rata tertinggi sebesar $-21,4 \mathrm{~dB}$. Selanjutnya buah mangga matang sekali sebesar $-22,8 \mathrm{~dB}$, mangga mengkal sebesar $-25,4 \mathrm{~dB}$ dan terakhir mangga mentah sebesar $-33,4 \mathrm{~dB}$. Berdasarkan hasil pengujian total padatan terlarut yaitu buah mangga matang di pohon $21.18^{\circ}$ BRIX, mangga matang sekali $20.53{ }^{\circ}$ BRIX, mangga mengkal $14.76^{\circ}$ BRIX, dan mangga mentah $8.93{ }^{\circ}$ BRIX. Hal ini menunjukkan nilai yang sebanding antara nilai $S_{21}$ dengan hasil pengukuran kadar gula. 


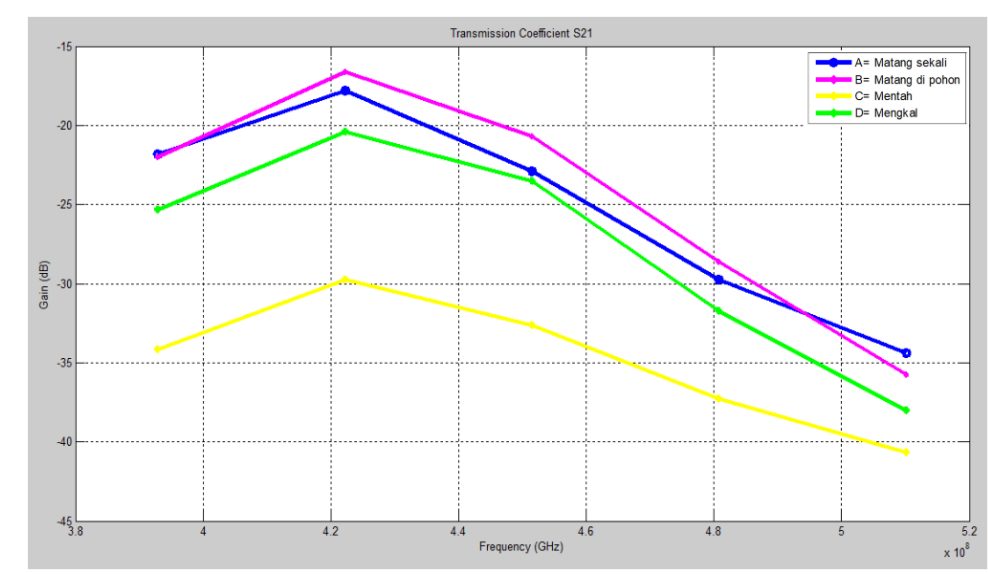

Gambar 12. Nilai gain $S_{21}$ pada rentang frekuensi $0,39-0,51 \mathrm{GHz}$

\section{Hubungan Nilai Impedansi dengan Kadar Gula}

Tren hubungan nilai impedansi dengan kadar gula terlihat pada rentang frekuensi rendah yaitu pada frekuensi 410 - $470 \mathrm{MHz}$. Pada frekuensi ini, nilai impedansi memiliki tren yang sama dengan data hasil pengukuran kadar gula. Urutan nilai rata-rata tingkat kemanisan buah berdasarkan pengujian total padatan terlarut yaitu buah mangga matang di pohon $21,18^{\circ} \mathrm{BRIX}$, mangga matang sekali $20,53{ }^{\circ}$ BRIX, mangga mengkal $14,76^{\circ}$ BRIX, dan mangga mentah 8,93 ${ }^{\circ}$ BRIX. Hasil ini berbanding linier dengan nilai impedansinya yaitu buah mangga matang di pohon 0,073 , mangga matang sekali 0,067, mangga mengkal 0,057\%, dan mangga mentah 0,032 seperti tampak pada gambar 13. Sehingga dari hasil kedua pengukuran tersebut menunjukkan hubungan yang sama antara nilai impedansi dengan kadar gulanya.

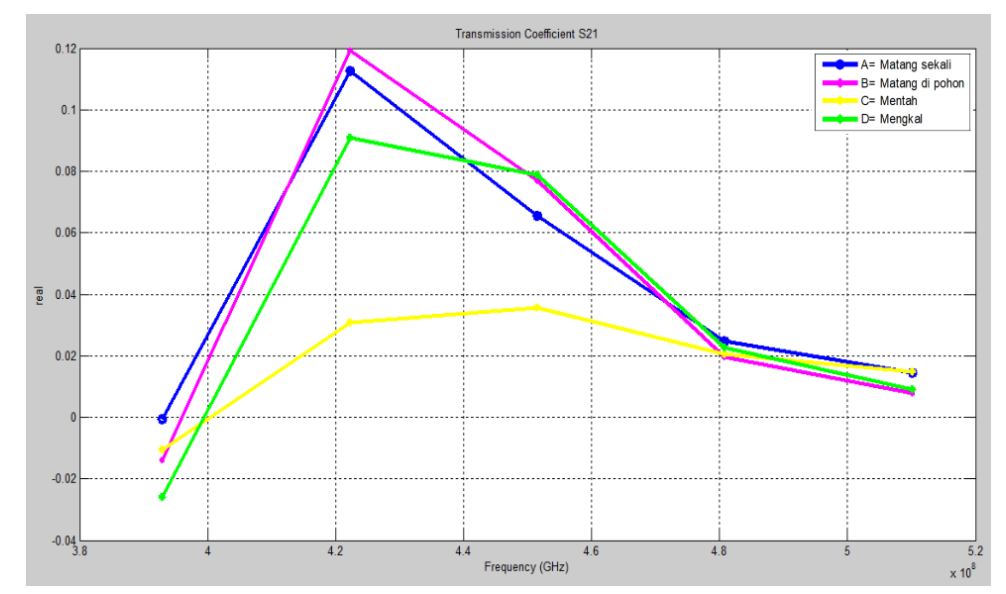

Gambar 13 Nilai Impedansi real $S_{21}$ pada rentang frekuensi $0,39-0,51 \mathrm{GHz}$

\section{KESIMPULAN}

Sensor double ring resonator dapat mendeteksi dan membedakan tingkat kematangan buah mangga berdasarkan nilai $S_{21}$ pada rentang frekuensi 0,39-0,49 GHz. Pada rentang frekuensi tersebut buah mangga yang matang dipohon memiliki nilai gain rata-rata sebesar $21,4 \mathrm{~dB}$, buah mangga matang sekali sebesar $-22,8 \mathrm{~dB}$, mangga mengkal sebesar $-25,4 \mathrm{~dB}$ dan terakhir mangga mentah sebesar $-33,4 \mathrm{~dB}$. 
Karakterisasi buah mangga juga dapat dilakukan berdasarkan nilai impedansinya. Hal ini terlihat pada rentang frekuensi rendah yaitu pada frekuensi $410-470 \mathrm{MHz}$ nilai impedansi yang dihasilkan berbeda antara satu dengan yang lainnya. Nilai impedansi rata-rata buah mangga yang matang di pohon sebesar 0,073 , mangga matang sekali 0,067 , mangga mengkal $0,057 \%$, dan mangga mentah 0,032 .

\section{DAFTAR PUSTAKA}

Dimas, G. dan Sutojo, T., (2015). Analisis Klasifikasi Tingkat Kematangan Buah Mangga Manalagi Menggunakan CBIR (Content Based Image Retrieval) Bedasarkan Warna.Universitas Dian Nuswantoro Semarang.

Harshitha, T. S., Ilaria M. dan Marco Spirito. 2017. Dielectric measurements of mangoes from $0.5 \mathrm{GHz}$ to $20 \mathrm{GHz}$ using a custom open-ended coaxial probe. Proceedings of the 47 th European Microwave Conference. Nuremberg, Germany.

Kemendag. 2017. Warta Ekspor. Direktur Jenderal Pengembangan Ekspor Nasional Kementerian Perdagangan Republik Indonesia. Edisi : PEN/MJL/008/7/2017

Monai, K., Anal M., dan Chnwong P. 2004 Nondestructive Measurement for Mango Inspection. International Symposium on Communications and Information Technologies 2004 ( ISCIT 200.1 ) Sapporo, Japan. October 26- 29.2004.

Oktavianto, Y., Sunaryo, dan Suryanto, A. (2015). Karakterisasi Tanaman mangga (mangifera indica 1.) Cantek, Ireng, Empok, Jempol Di Desa Tiron, Kecamatan Banyakan Kabupaten Kediri. Jurnal Produksi Tanaman, Volume 3, Nomor 2, Maret 2015, hlm. $91-97$.

Reyes, A., Yarlequ M., Castro W., dan Chuquizuta S. 2017. The Freshness Analysis of an Apple and a Potato Using Dielectric Properties at the Microwave Frequency Region. Progress In Electromagnetics Research Symposium (PIERS), St Petersburg, Russia

Riska S. Y., Cahyani L., dan Rosadi M., I. (2015). Klasifikasi Jenis Tanaman Mangga Gadung dan Mangga Madu Berdasarkan Tulang Daun. Jurnal Buana Informatika, Volume 6, Nomor 1, Januari 2015: 41-50.

Syafrin, R., R., Muvianto, C., M., O. dan Sasongko S., M., A. 2018. Deteksi Keaslian Madu Trigona Berdasarkan Nilai Dielektrik Dan Konduktivitas Menggunakan Teknik Open - Ended Coaxial Cavity Resonator Pada Frekuensi 100 - 1000 MHz. Jurnal Dielektrika Vol 5 No 1 (2018).

Wahyudi, A. dan Dewi R.. 2017. Upaya perbaikan kualitas dan produksi buah menggunakan teknologi budidaya sistem ToPAS pada 12 varietas semanga hibrida. Jurnal Penelitian Pertanian 17(1): 17-25.

You, K.,Y., Mun, H., K., Dimon MN (2013). Broken rice detection based on microwave measurement technique using microstrip wide-ring sensor and microstrip coupledline sensor. AJCS 7(13):2079-2090. ISSN:1835-2707.

Zhang, E., Xue, C., dan Jinghui. 2018. Design and Human Trials of Microwave Noninvasive Blood Glucose Detection Sensor. IEEE International Symposium on Antennas and Propagation \& USNC/URSI National Radio Science Meeting. Boston, MA, USA. 